Case Report

\title{
Tracheal Lobular Capillary Haemangioma: A Rare Benign Cause of Recurrent Haemoptysis
}

\author{
Metesh Nalin Acharya, Konstantinos Kotidis, and Mahmoud Loubani \\ Department of Cardiothoracic Surgery, Castle Hill Hospital, Cottingham, UK \\ Correspondence should be addressed to Metesh Nalin Acharya; metesh.acharya@doctors.org.uk
}

Received 2 July 2016; Accepted 11 August 2016

Academic Editor: Sibu P. Saha

Copyright (C) 2016 Metesh Nalin Acharya et al. This is an open access article distributed under the Creative Commons Attribution License, which permits unrestricted use, distribution, and reproduction in any medium, provided the original work is properly cited.

Lobular capillary haemangioma ( $\mathrm{LCH})$, previously known as pyogenic granuloma, is a benign vascular lesion commonly found within the oral and nasal cavity. However, it is rarely encountered within the trachea, where presenting features include recurrent haemoptysis, cough, and wheeze. We here describe a case of a $7 \mathrm{~mm}$ tracheal LCH in a 56-year-old woman, which was successfully resected at interventional bronchoscopy using biopsy forceps. Clinicians should be aware of tracheal LCH in the differential diagnosis for recurrent haemoptysis.

\section{Introduction}

Tracheal tumours represent only $2 \%$ of all upper respiratory tract tumours [1]. Those in adults are usually malignant; benign tumours, including chondroma, papilloma, and fibroma most often occur in the proximal third of the trachea in adults and its distal third in children [2]. Lobular capillary haemangioma (LCH), previously called pyogenic granuloma, commonly presents on the lip, nose, oral cavity, or tongue $[3,4]$ but has rarely been reported within the trachea. We here report the case of a 56-year-old woman with a tracheal LCH managed by bronchoscopic resection using biopsy forceps.

\section{Case Presentation}

A 56-year-old Caucasian woman was referred to our institution with several episodes of mild haemoptysis over the preceding three months. She denied associated chest pain, exertional dyspnoea, dysphagia, syncope, weight loss, anorexia, fever, and rigors. There was no history of airway instrumentation or foreign body aspiration. Her medical background included laparoscopic sterilisation, oesophagitis, meningitis, and hypertension. She was a nonsmoker and consumed alcohol within normal limits.

Physical examination was unremarkable and routine blood investigations and chest radiograph were normal.
Pulmonary function was satisfactory with $\mathrm{FEV}_{1} 3.50 \mathrm{~L}$ and FVC 3.85 L. Computed tomography (CT) scanning (Figure 1) demonstrated a pedunculated lesion arising from the right tracheal wall and projecting into its lumen. Following case discussion at a multidisciplinary team meeting, patient consent was obtained for rigid bronchoscopy under general anaesthetic. A $7 \mathrm{~mm}$ polypoid mass with a small pedicle was identified $2 \mathrm{~cm}$ inferior to the vocal cords on the right tracheal wall and resected in entirety utilising biopsy forceps. Haemostasis was achieved following local application of electrocautery and adrenaline-soaked swabs, and the patient was discharged home the next day. The patient was asymptomatic at six-month and one-year follow-up with no radiological or bronchoscopic evidence of disease recurrence.

Histological examination (Figure 2) of the surgical specimen demonstrated nodular proliferation of endothelial cells and capillary-type lumina separated by mildly oedematous and inflamed stroma, suggestive of a capillary haemangioma. There was no pathological evidence of dysplasia or malignancy.

\section{Discussion}

Tracheal tumours account for less than $2 \%$ of all upper respiratory tract tumours [1] and are usually malignant in 


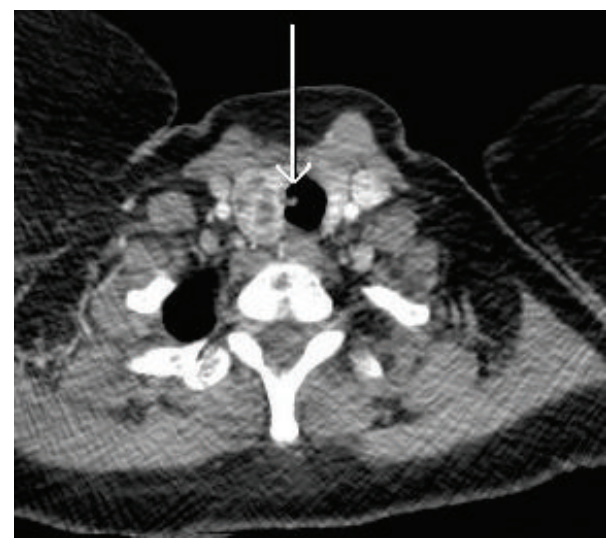

FIGURE 1: Computed tomography scan demonstrating a pedunculated lesion (arrow) projecting from the right tracheal wall into its lumen.

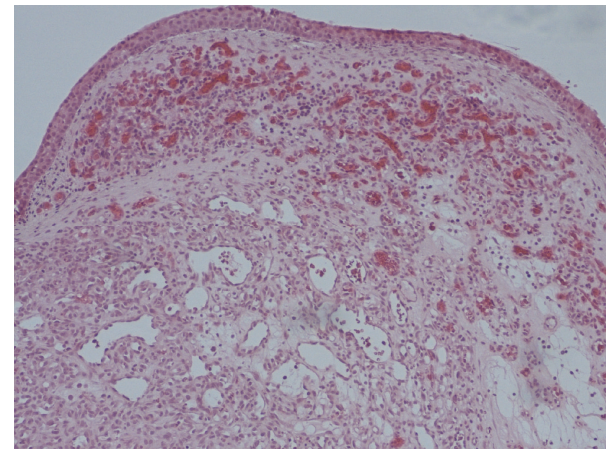

FIGURE 2: Histopathological analysis of the resected specimen demonstrates capillary haemangioma covered by metaplastic squamous epithelium (haematoxylin and eosin stain; original magnification $\times 100$ ).

adult populations. Commoner benign tumours in this region include chondroma, papilloma, and fibroma, with less than $10 \%$ being vascular in origin [5].

Lobular capillary haemangioma is a benign lesion characterised microscopically by a distinctive lobular arrangement of capillaries in an oedematous, fibroblastic stoma [2, 3, 6]. The traditionally ascribed term pyogenic granuloma is inaccurate, since the tumour neither is caused by bacterial infection, nor is a true granuloma [7]. Younger lesions are typically vascular in appearance but may become collagenous with age [8]. Tracheal LCH usually presents as a painless red-purple nodule or papule associated with cough, wheeze, or haemoptysis, developing rapidly over a period of days to weeks. It may rarely manifest with airway haemorrhage [9] or obstruction [10].

The surface epithelium is often ulcerated, predisposing to invasion by microorganisms. Commonly found on the lip, nose, oral cavity, and tongue $[3,4]$, occurrence within the tracheobronchial tree is extremely rare and infrequently described in medical literature.

Although the precise aetiological mechanisms accounting for LCH are not yet fully ascertained, traumatic insults, hormonal imbalances during pregnancy, viral and bacterial infections, microscopic arteriovenous malformations, angiogenic growth factors, and cytogenetic abnormalities have been proposed as causative factors.

Chest radiography and computed tomography findings may be inconclusive, and thus bronchoscopy with biopsy plays a key role in diagnosis of tracheal $\mathrm{LCH}$, whilst additionally affording the opportunity for therapeutic intervention. Endoscopic appearances are nonspecific and may mimic adenoma, carcinoma, or carcinoid tumour. For this reason, decision for surgical resection should be avoided until a definitive histopathological diagnosis is established.

The extent and size of the lesion, as well as patient age and comorbidities, require consideration prior to any therapeutic intervention for LCH. Despite their benign nature, local recurrence is common and thus surgical excision remains the treatment of choice. Nevertheless, mucocutaneous LCH is also amenable to various nonsurgical techniques including snare electrocautery, cryotherapy, YAG laser therapy, and plaque radiation. In the present case, we were able to safely remove the culprit lesion with biopsy forceps alone and with minimal bleeding owing to its small vascular pedicle.

To our knowledge, there are only 14 reports of tracheal LCH in English medical literature to date (Table 1). Irani et al. successfully extracted a $2-3 \mathrm{~mm} \mathrm{LCH}$ occurring $3 \mathrm{~cm}$ below the vocal cords in a 72 -year-old female with flexible biopsy forceps [3]. Endoscopic techniques were employed by $\mathrm{Xu}$ et al. [11] and Madhumita et al. [2], who resected a $4 \mathrm{~mm}$ tracheal LCH in a 64-year-old male and a $1 \mathrm{~cm}$ tracheal LCH in a 40-year-old female, respectively. Chawla et al. combined endoscopic excision and laser therapy for distal tracheal LCH in a 62-year-old male [12]. Chen et al. utilised cryotherapy to remove a $2 \mathrm{~cm}$ tracheal $\mathrm{LCH}$ which occluded the majority of the tracheal lumen in a 14-year-old girl [13]. Cryotherapy was similarly applied for a $1.5 \mathrm{~cm}$ tracheal LCH near the carina in the report by Udoji and Bechara [14]. Two $4 \mathrm{~mm}$ lesions were excised with biopsy forceps and electrocautery in Porfyridis's report of a 17-year-old boy with recurrent haemoptysis [6]. Electrocautery loop snaring was also used in a 22 -year-old male with a $1.5 \mathrm{~cm}$ LCH of the posterior tracheal wall in the report by Amy and Enrique [4], as well as in a 57-yearold male by Kalanjeri et al. [15]. Following multiple poor responses to electrocautery and argon plasma coagulation, Shen et al. [16] utilised brachytherapy successfully to control a $2 \mathrm{~cm}$ tracheal LCH in a 35-year-old male. Dabó et al. required photocoagulation to achieve haemostasis following significant bleeding on removal of a tracheal LCH using rigid biopsy forceps in a 51-year-old female [17]. Zambudio et al. performed arterial embolisation to control massive haemoptysis from a bleeding tracheal capillary haemangioma in a 66-year-old female with thrombocytopaenia [9]. Circulatory assistance with extracorporeal membrane oxygenation was employed as a precautionary measure when debulking a large LCH in a 23-year-old pregnant female in the report by Prakash et al. [10]. Putora et al. propose this lesion occurring as a consequence of erlotinib chemotherapy in a 64-yearold patient with squamous cell lung cancer; interestingly, complete resolution of the $\mathrm{LCH}$ was noted on discontinuation of erlotinib and no invasive intervention was necessary [18]. 
TABLE 1: Summary of previously reported cases of tracheal lobular capillary haemangioma.

\begin{tabular}{|c|c|c|c|c|c|}
\hline Author & $\begin{array}{c}\text { Age (years), } \\
\text { M/F }\end{array}$ & Tumour size & Tumour location & Treatment & Outcome \\
\hline $\begin{array}{l}\text { Madhumita et } \\
\text { al. [2] }\end{array}$ & $40, \mathrm{~F}$ & $10 \times 5 \mathrm{~mm}$ & $\begin{array}{l}\text { Upper third of right } \\
\text { anterolateral tracheal } \\
\text { wall }\end{array}$ & $\begin{array}{l}\text { Endoscopic } \\
\text { resection }\end{array}$ & Good at 1 year \\
\hline Irani et al. [3] & $72, \mathrm{~F}$ & $2-3 \mathrm{~mm}$ & $\begin{array}{l}3 \mathrm{~cm} \text { below vocal } \\
\text { cords }\end{array}$ & $\begin{array}{l}\text { Endoscopic } \\
\text { resection }\end{array}$ & Good at 1 year \\
\hline $\begin{array}{l}\text { Amy and } \\
\text { Enrique [4] }\end{array}$ & $22, \mathrm{M}$ & $10-15 \mathrm{~mm}$ & $\begin{array}{c}3 \mathrm{~cm} \text { above carina on } \\
\text { left posterior tracheal } \\
\text { wall }\end{array}$ & Electrocautery & Good \\
\hline $\begin{array}{l}\text { Porfyridis et al. } \\
{[6]}\end{array}$ & $17, \mathrm{M}$ & $4 \mathrm{~mm}$ & $\begin{array}{c}\text { Upper third of left } \\
\text { anterolateral tracheal } \\
\text { wall }\end{array}$ & $\begin{array}{l}\text { Endoscopic } \\
\text { resection }\end{array}$ & Good at 1 year \\
\hline $\begin{array}{l}\text { Zambudio et al. } \\
\text { [9] }\end{array}$ & $66, \mathrm{~F}$ & $\begin{array}{l}\text { Occluding } \\
30-40 \% \text { of } \\
\text { airway }\end{array}$ & $\begin{array}{l}\text { Between first and } \\
\text { third tracheal rings }\end{array}$ & Embolisation & Good at 1 year \\
\hline $\begin{array}{l}\text { Prakash et al. } \\
{[10]}\end{array}$ & $23, \mathrm{~F}$ & $20 \times 40 \mathrm{~mm}$ & Posterior tracheal wall & $\begin{array}{l}\text { Endoscopic } \\
\text { resection with } \\
\text { extracorporeal } \\
\text { membrane } \\
\text { oxygenation } \\
\end{array}$ & Good \\
\hline Xu et al. [11] & $64, \mathrm{M}$ & $3-4 \mathrm{~mm}$ & $\begin{array}{c}\text { Left anterolateral } \\
\text { tracheal wall }\end{array}$ & $\begin{array}{c}\text { Endoscopic } \\
\text { resection }\end{array}$ & $\begin{array}{c}\text { Good at } 8 \\
\text { months }\end{array}$ \\
\hline $\begin{array}{l}\text { Chawla et al. } \\
{[12]}\end{array}$ & $62, \mathrm{M}$ & Unknown & $\begin{array}{l}\text { Distal right tracheal } \\
\text { wall }\end{array}$ & $\begin{array}{c}\text { Endoscopic } \\
\text { resection and laser } \\
\text { therapy }\end{array}$ & Unknown \\
\hline Chen et al. [13] & $14, \mathrm{~F}$ & $15-20 \mathrm{~mm}$ & $\begin{array}{l}\text { Lower third of } \\
\text { anterior tracheal wall }\end{array}$ & $\begin{array}{c}\text { Cryotherapy and } \\
\text { argon plasma } \\
\text { coagulation }\end{array}$ & $\begin{array}{l}\text { Good at } 3 \\
\text { months }\end{array}$ \\
\hline $\begin{array}{l}\text { Udoji and } \\
\text { Bechara [14] } \\
\end{array}$ & $55, \mathrm{M}$ & $4 \times 5 \mathrm{~mm}$ & $\begin{array}{c}\text { Distal left lateral } \\
\text { tracheal wall }\end{array}$ & Cryotherapy & $\begin{array}{c}\text { Good at } 3 \\
\text { months }\end{array}$ \\
\hline $\begin{array}{l}\text { Kalanjeri et al. } \\
{[15]}\end{array}$ & $57, \mathrm{M}$ & $\begin{array}{l}\text { Occluding } \\
70 \% \text { of } \\
\text { airway } \\
\end{array}$ & $\begin{array}{l}\text { Posterior middle } \\
\text { tracheal wall }\end{array}$ & Electrocautery & Unknown \\
\hline Shen et al. [16] & $35, \mathrm{M}$ & $15-20 \mathrm{~mm}$ & $\begin{array}{c}\text { Lateral wall of } \\
\text { proximal left main } \\
\text { bronchus }\end{array}$ & Brachytherapy & Good at 2 years \\
\hline Dabó et al. [17] & $51, \mathrm{~F}$ & Unknown & $\begin{array}{l}\text { Lower third of left } \\
\text { lateral tracheal wall }\end{array}$ & $\begin{array}{c}\text { Endoscopic } \\
\text { resection and laser } \\
\text { photocoagulation }\end{array}$ & $\begin{array}{l}\text { Good at } 27 \\
\text { months }\end{array}$ \\
\hline Putora et al. [18] & $64, \mathrm{M}$ & Unknown & Distal tracheal wall & $\begin{array}{c}\text { Spontaneous } \\
\text { remission on } \\
\text { cessation of } \\
\text { erlotinib for lung } \\
\text { cancer }\end{array}$ & Good \\
\hline Present case & $56, \mathrm{~F}$ & $7 \mathrm{~mm}$ & $\begin{array}{c}2 \mathrm{~cm} \text { below vocal } \\
\text { cords on right } \\
\text { tracheal wall }\end{array}$ & $\begin{array}{l}\text { Endoscopic } \\
\text { resection and } \\
\text { electrocautery }\end{array}$ & Good at 1 year \\
\hline
\end{tabular}

In conclusion, $\mathrm{LCH}$ is a benign lesion rarely found within the trachea. Common presenting features may include recurrent haemoptysis, cough, and wheeze. Symptomatic lesions are usually amenable to direct evaluation and removal via interventional bronchoscopic techniques.

\section{Consent}

Written informed consent was obtained from the patient for publication of this paper.

\section{Competing Interests}

The authors declare that there are no competing interests regarding the publication of this paper.

\section{Acknowledgments}

The authors are thankful to Dr. Martin Peters, histopathologist, for his interpretation of the specimen microscopy slides. 


\section{References}

[1] M. I. Perelman and N. S. Koroleva, "Primary tumours of the trachea," in International Trends in General Thoracic Surgery, H. C. Grillo and H. Eschapasse, Eds., pp. 91-110, WB Saunders, Philadelphia, Pa, USA, 1987.

[2] K. Madhumita, K. P. Sreekumar, H. Malini, and R. Indudharan, "Tracheal haemangioma: case report," Journal of Laryngology and Otology, vol. 118, no. 8, pp. 655-658, 2004.

[3] S. Irani, T. Brack, M. Pfaltz, and E. W. Russi, "Tracheal lobular capillary hemangioma: a rare cause of recurrent hemoptysis," Chest, vol. 123, no. 6, pp. 2148-2149, 2003.

[4] F. T. Amy and D.-G. Enrique, "Lobular capillary hemangioma in the posterior trachea: a rare cause of hemoptysis," Case Reports in Pulmonology, vol. 2012, Article ID 592524, 3 pages, 2012.

[5] K. C. Y. Sie and D. A. Tampakopoulou, "Hemangiomas and vascular malformations of the airway," Otolaryngologic Clinics of North America, vol. 33, no. 1, pp. 209-220, 2000.

[6] I. Porfyridis, C. Zisis, K. Glinos et al., "Recurrent cough and hemoptysis associated with tracheal capillary hemangioma in an adolescent boy: a case report," Journal of Thoracic and Cardiovascular Surgery, vol. 134, no. 5, pp. 1366-1367, 2007.

[7] S. E. Mills, P. H. Cooper, and R. E. Fechner, "Lobular capillary hemangioma: the underlying lesion of pyogenic granuloma: a study of 73 cases from the oral and nasal mucous membranes," The American Journal of Surgical Pathology, vol. 4, no. 5, pp. 470-479, 1980.

[8] H. Jafarzadeh, M. Sanatkhani, and N. Mohtasham, "Oral pyogenic granuloma: a review," Journal of Oral Science, vol. 48, no. 4, pp. 167-175, 2006.

[9] A. R. Zambudio, M. J. Roca Calvo, J. Torres Lanzas, J. García Medina, and P. Parrilla Paricio, "Massive hemoptysis caused by tracheal hemangioma treated with interventional radiology," Annals of Thoracic Surgery, vol. 75, no. 4, pp. 1302-1304, 2003.

[10] S. Prakash, S. Bihari, and U. Wiersema, "A rare case of rapidly enlarging tracheal lobular capillary hemangioma presenting as difficult to ventilate acute asthma during pregnancy," $B M C$ Pulmonary Medicine, vol. 14, no. 1, article 41, 2014.

[11] Q. Xu, X. Yin, J. Sutedjo, J. Sun, L. Jiang, and L. Lu, "Lobular capillary haemangioma of the trachea," Archives of Iranian Medicine Journal, vol. 18, pp. 127-129, 2015.

[12] M. Chawla, C. Stone, and M. J. Simoff, "Lobular capillary hemangioma of the trachea: the second case," Journal of Bronchology and Interventional Pulmonology, vol. 17, no. 3, pp. 238240, 2010.

[13] E. Chen, X. Yu, R. Zhang, P. Wang, and K. Ying, "A large tracheal capillary hemangioma treated with interventional bronchoscopy," Respiratory Medicine CME, vol. 4, no. 2, pp. 6061, 2011.

[14] T. N. Udoji and R. I. Bechara, "Pyogenic granuloma of the distal trachea: a case report," Journal of Bronchology and Interventional Pulmonology, vol. 18, no. 3, pp. 281-284, 2011.

[15] S. Kalanjeri, A. Kumar, S. Mukhopadhyay, and A. C. Mehta, "Lobular capillary hemangioma ('Pyogenic Granuloma') of the Trachea," American Journal of Respiratory and Critical Care Medicine, vol. 193, no. 12, pp. 1429-1430, 2016.

[16] J. Shen, H.-R. Liu, and F.-Q. Zhang, "Brachytherapy for tracheal lobular capillary haemangioma (LCH)," Journal of Thoracic Oncology, vol. 7, no. 5, pp. 939-940, 2012.

[17] H. Dabó, R. Gomes, N. Teixeira, G. Teixeira, G. Fernandes, and A. Magalhães, "Tracheal lobular capillary hemangioma treated with laser photocoagulation," Jornal Brasileiro de Pneumologia, vol. 42, no. 1, pp. 72-73, 2016.

[18] P. M. Putora, G. Benz, R. Rodriguez, M. Brutsche, and M. Früh, "Tracheal granuloma pyogenicum with erlotinib treatment for lung cancer," European Respiratory Journal, vol. 38, no. 5, pp. 1228-1230, 2011. 


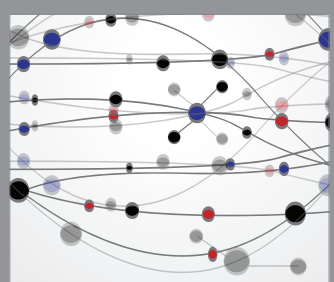

The Scientific World Journal
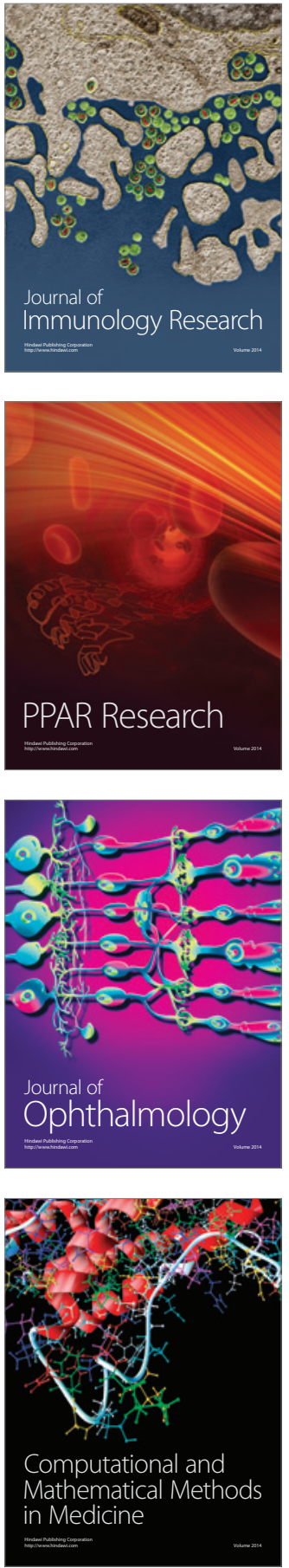

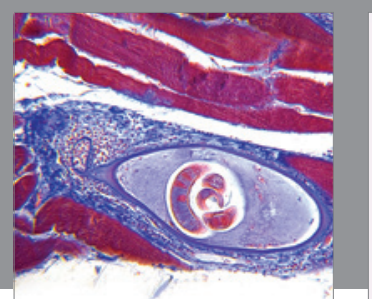

Gastroenterology Research and Practice

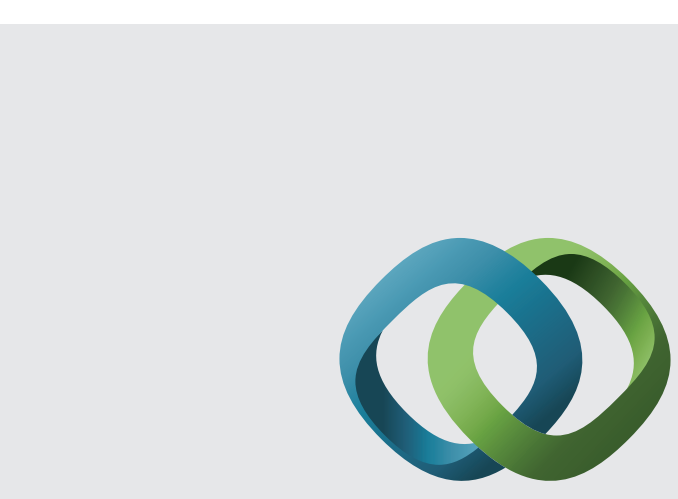

\section{Hindawi}

Submit your manuscripts at

http://www.hindawi.com
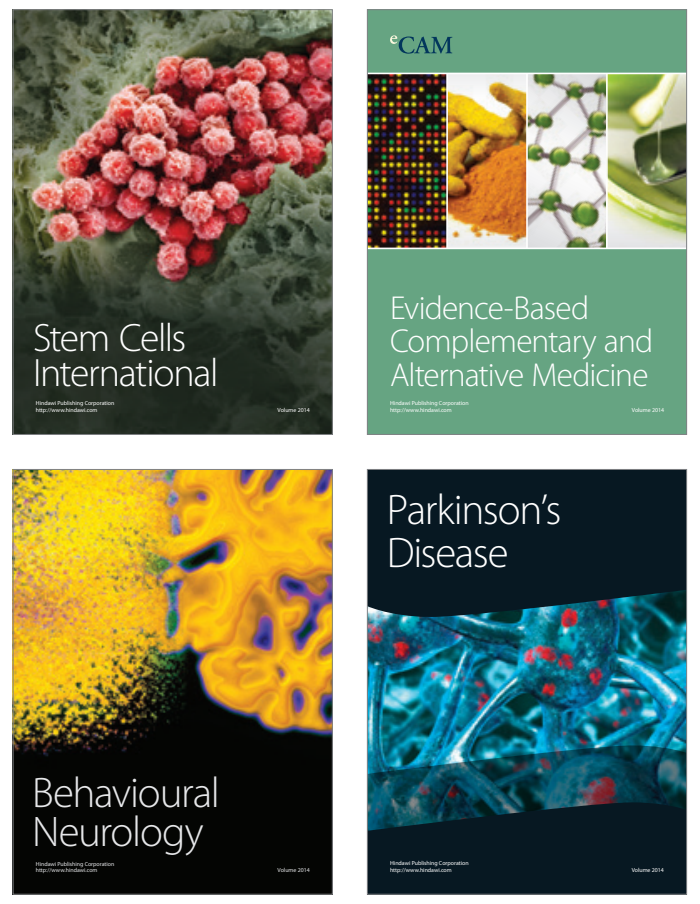
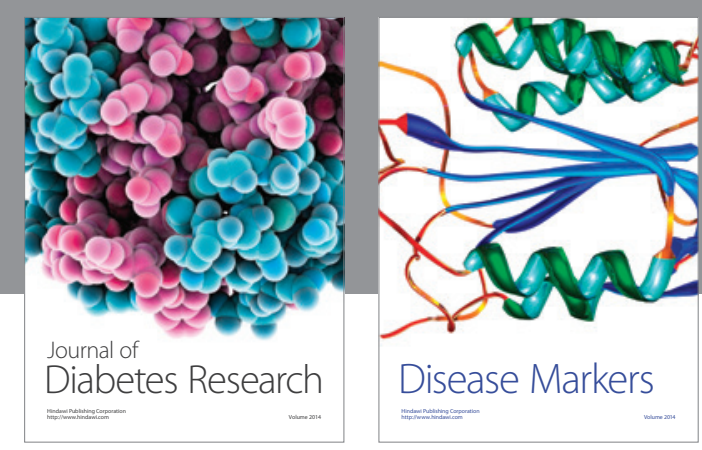

Disease Markers
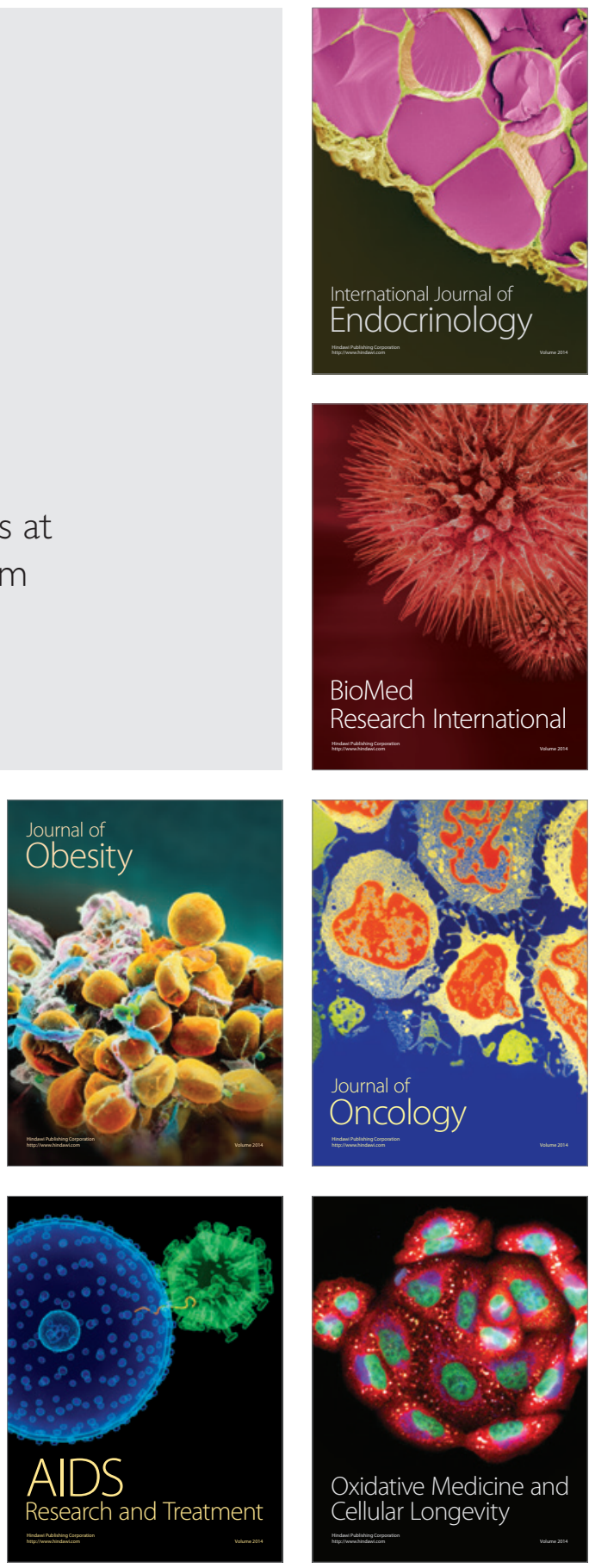